"The role of servant leadership and emotional intelligence in managerial performance in a commercial banking sector in Zimbabwe"

\begin{tabular}{ll} 
AUTHORS & $\begin{array}{l}\text { Jeskinus Z. Mukonoweshuro } \\
\text { Cleopas Sanangura } \\
\text { Elias Munapo }\end{array}$ \\
& $\begin{array}{l}\text { Jeskinus Z. Mukonoweshuro, Cleopas Sanangura and Elias Munapo (2016). The } \\
\text { role of servant leadership and emotional intelligence in managerial performance } \\
\text { in a commercial banking sector in Zimbabwe . Banks and Bank Systems, 11(3), } \\
94-108 . \text { doi:10.21511/bbs.11(3).2016.10 }\end{array}$ \\
\hline ARTICLE INFO & http://dx.doi.org/10.21511/bbs.11(3).2016.10 \\
\hline DOI & Wednesday, 12 October 2016 \\
\hline RELEASED ON & "Banks and Bank Systems" \\
\hline JOURNAL & LLC "Consulting Publishing Company "Business Perspectives" \\
\hline FOUNDER &
\end{tabular}

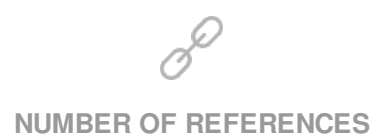

0

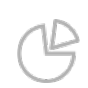

NUMBER OF FIGURES

0

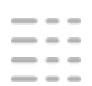

NUMBER OF TABLES

0

(C) The author(s) 2022. This publication is an open access article. 
Jeskinus Z. Mukonoweshuro (South Africa), Cleopas Sanangura (South Africa), Elias Munapo (South Africa)

\title{
The role of servant leadership and emotional intelligence in mana- gerial performance in a commercial banking sector in Zimbabwe
}

\begin{abstract}
The constructs of servant leadership (SL) and emotional intelligence (EI) have gained considerable interest in the discipline of managerial leadership, both within academic discourse and in the human capital management and development arena. However, empirical evidence showed the need for further research on both constructs using the mixed methods approach. The purpose of this research was to explore the role of an integrated servant leadership and emotional intelligence leadership skills program in enhancing leadership performance in Zimbabwe's commercial banking sector. A mixed methods research triangulation concurrent design was adopted for the research study conducted from 2014 to 2015. A survey questionnaire was used to collect quantitative data from 211 middle, senior and executive managerial staff in the commercial banking sector. SPSS version 22.0 was used to analyze the quantitative data. Qualitative data were collected from a purposive sample of eight senior to executive managers using a structured interview guide and multimedia recording equipment. The qualitative data were analyzed using NVIVO version 10 software package to create themes. The findings showed that servant leadership and emotional intelligence characteristics complement each other and both constructs can be integrated into a managerial leadership program used to develop leadership soft skills or competencies. The findings also showed that both SL and EI skills had a positive influence in enhancing the managers' effectiveness in undertaking leadership responsibilities and on leadership qualitative performance measures such as articulating vision and strategy, building and sustaining productive organizational culture, development and retention of talent, enhancing employee engagement, improving stakeholder relationship management, retaining bank customers, promotion of diversity, value creation and community involvement. The study led to the development of an integrated SL and EI soft skills leadership program and model which, if implemented, could lead to leadership skills development and performance enhancement.
\end{abstract}

Keywords: leadership, competencies, servant leadership and emotional intelligence.

JEL Classification: E58, G21, M12.

\section{Introduction}

The study researched the role of servant leadership and emotional intelligence in building the nontechnical leadership abilities for managerial leadership in the positions of middle, senior and executive management in the commercial banking sector in Zimbabwe in order to improve organizational leadership performance in selected areas which include articulating vision and strategy, building and sustaining productive organizational culture, development and retention of talent, enhancing employee engagement, improving stakeholder relationship management, retaining bank customers, value creation and community involvement. Servant leadership (SL) is a concept that originated from the writings by Greenleaf (1977, cited in Rachmawati \& Lantu, 2014, p. 389) who likened a leader as a servant to his followers and that the leader focuses on fulfilling the needs of the followers and the leader pursues the principle of egalitarianism, i.e., "first

(C) Jeskinus Z. Mukonoweshuro, Cleopas Sanangura, Elias Munapo, 2016.

Jeskinus Z. Mukonoweshuro, Doctor of Business Administration, Graduate School of Business \& Leadership, University of KwaZuluNatal, Westville Campus, South Africa.

Cleopas Sanangura, Doctoral Research Supervisor, Graduate School of Business \& Leadership, University of KwaZulu-Natal, Westville Campus, South Africa.

Elias Munapo, Associate Professor, School of Economics and Decision Sciences, North West University, Mafeking, South Africa. among equals" which enables him or her to influence followers to achieve results through persuasion (Rachmawati \& Lantu, 2014, p. 389). To be effective in achieving desired organizational goals, a leader had to acquire and put into practice certain leadership behavioral attributes or characteristics which include listening, empathy, healing relationships, conceptualization, stewardship, commitment to the growth of people and building community (Anderson, 2009, p. 5). Over several decades, writers such as Spears (1998), Russel (2001), Russel \& Stone (2002), Patterson (2003), Sendjaya, Sarros and Sandora (2008) and Van Dierendonck \& Nuijten (2010) developed various models on servant leadership which are largely complementary.

Emotional intelligence (EI) is a construct that was developed from earlier work by Thorndike (1921, cited in Maulding, Peters, Leonard \& Sparkman, 2012, p. 21) when he was writing about social intelligence and Gardner's (1993, cited in Maulding et al., 2012, p. 21) writings on various forms of intelligences. Salovey \& Mayer (1990, p. 189) were credited with coining the term 'emotional intelligence' and they defined EI as "a form of social intelligence that involves the ability to monitor one's own and others' feelings and emotions, to discriminate among them, and to use this information to guide one's thinking and actions". EI is perceived to provide the ability to understand one's own feelings, have empathy for the feelings of 
others and to regulate one's and other people's emotions to enhance living (Ugwu, 2011, p. 137).

Various EI models were developed and these include the abilities model by Mayer, Caruso and Salovey (2000, cited in Prins, Van Niekerk \& Weyers, 2011, p. 66) comprising four components: emotional perception and identification, emotional facilitation of thought, emotional understanding and emotional management. Bar On (1998, cited in Khalili, 2013, p. 61) developed the mixed cognitive abilities and personal traits EI model comprising five components, namely, intrapersonal, interpersonal, adaptability, stress management and public mood abilities. Perhaps the most talked about EI model in organizations is the Goleman (2001, p. 27) competency model comprising four components: self-awareness, social awareness, self-management and relationship management competencies (Beigi \& Shirmohammadi, 2011, p. 554).

The paper highlights the agenda or purpose of the research, the problem statement, strategic research question, operational research questions and the thesis statement. Extant literature was reviewed, covering the definitions, origins, theories and models of servant leadership and emotional intelligence and selected empirical studies on how the two constructs help to build managerial leadership skills and performance. The paper highlights the mixed methods research design applied in data collection, the reliability and validity of the data collection instruments used and how the data were analyzed. Research findings are discussed and interpreted in order to highlight the practical implications of the findings to the research community and to the professional world of management and leadership. The paper concludes by looking at the issues of research study limitations, the conclusions of the study, contributions made from the study and the recommendations. The last sections of the paper provide acknowledgements and references used in the writing up this paper.

\section{Research problem}

This study was undertaken after identifying the following research problem. Organizational leaders, especially middle, senior and executive managers play a critical role in crafting and implementing business strategies and models that ensure the achievement of set goals. Achievement of financial targets like profitability, return on equity and cost to income ratio require that managerial leaders also focus on the non-financial performance measures as well. The problem prompting this research study was the inadequate evidence of relationship building and management by bank managerial staff towards stakeholders which often resulted in either employee relationship challenges with staff, customer disengagement, and poor regulatory relation- ships, to highlight a few. These manifestations could have been the result of insufficient soft skills and inadequate development of the soft skills for managerial leadership in the commercial banking sector in Zimbabwe. The thesis statement (Hofstee, 2009, p. 19) for the study was that the implementation of a SL and EI skills program would significantly contribute to the development of leadership soft skills and enhancement of organizational leadership performance.

\section{Literature review}

1.1. Definition of key terms. The overarching terms permeating the discussions in the paper are defined to create a common understanding.

1.1.1. Leadership. Leadership is viewed as the ability to influence, motivate and enable one's team to contribute to the effectiveness and success of an organization for its members (Anand \& Udayasuriyan, 2010, p. 65), while Hunter (2012, p. 28) defines leadership as "the skill of influencing people to work enthusiastically toward goals identified as being for the common good". Hunter (2012, p. 30) distinguishes between power and authority as they relate to leadership. Power is defined as the ability to force or coerce someone to do their will, even if they would choose not to (ibid). Authority is defined as "the skill of getting people to willingly do your will because of your personal influence" (ibid.). Leadership is, therefore, viewed more as a skill used to influence followers in an organization to work enthusiastically towards goals specifically identified for the common good while building relationships (Parris \& Peachey, 2013, p. 377; Hunter, 2012, p. 41).

1.1.2. Competencies. The concept of competency is defined as a capability or ability that leads to or causes effective performance (Emmerling \& Boyatzis, 2012, p. 7). Emmerling \& Boyatzis (2012, p. 7) argue that competencies represent related, but different sets of behavior organized around an underlying construct called 'intent' and that the behaviors are alternate manifestations of the intent, as appropriate in various situations or times; for example, listening to someone and asking him or her questions. Melchar \& Bosco (2010, p. 74) define leadership at the strategic level as "how leaders develop and facilitate the achievement of the mission and vision, develop values required for long-term success and implement these via appropriate [leadership] actions and behaviors, and are personally involved in ensuring that the organization's management system is developed and implemented" (Melchar \& Bosco, 2010, p. 74) Sharing a similar view, Boone \& Makhani (2012, p. 84) argue that leadership consists of a wide variety of well-recognized skills, behaviors and attitudes and, while skills and behaviors can be learned and honed through practice, attitudes tend to be linked to personality, perception, feelings and motivation. 
The concepts of leadership and competency are pertinent in this research which seeks to explore the role of servant leaders and emotional intelligence dimensions in building managerial leadership competencies or capabilities and how such capabilities could impact the non-financial performance deliverables expected of the leaders.

1.2. Servant leadership. The section reviews the literature on definitions, origin, theories and models of servant leadership (SL). Greenleaf (1977 cited in Parris \& Peachey, 2012, p. 379) who is perceived as the founder of the concept of SL, argues, "leadership was bestowed upon a man who was by nature a servant and servant leaders are distinguished by both their primary motivation to serve (what they do) and their self-construction (who they are), and from this conscious choice of 'doing' and 'being' they aspire to lead" (Sendjaya and Sarros, 2002, cited in Parris \& Peachey, 2011, p. 379).

Greenleaf (1977) cited in Reed, Vidaver-Cohen \& Colwell (2011, p. 416) placed servant leadership in an organizational leadership context when he argued that servant leaders are those who manage organizational challenges by subordinating personal interests to those of organizational stakeholders, and see leadership as an opportunity for service to individuals, organization, and community rather than as a vehicle to attain personal power and prestige. Patterson (2003) cited in Shekari \& Nikooparvar (2012, p. 55) added to the discourse on SL by defining servant leaders as those leaders who lead an organization by focusing on their followers, such that the followers are the primary concern and the organizational concerns are peripheral. Flint (2011, p. 1) defined a servant leader as "men and women who bring their purpose, passion, and character, and when combined with their God-given skills and abilities for leadership, bring out the best in people, helping a business to develop and implement a sustainable process for success". The words servant and leader are ordinarily viewed as being opposites and coining the term servant leadership creates a paradox (Spears, 2010, p. 26), or an "oxymoron", as they are two different roles to be undertaken by one person simultaneously wherein a leader is expected to both serve and lead (Rachmawati \& Lantu, 2014, p. 388). The concept of servant leadership was constructed from two terms, leader and servant, which are perceived as Shekari and Nikooparvar (2012, p. 55) highlighted that servant leadership is an emerging model of leadership characterized by its strong follower-centric, altruistic, moral/ethical, and spiritual values.

1.3. Emotional intelligence. The concept of EI is credited to Thorndike's (1921) work on social intelligence, Wechsler's (1940) proposition of nonintellective abilities, Gardner's (1983) work on mul- tiple intelligences and Goleman's (1983) conceptualization of personal intelligence (Maulding, Peters, Leonard and Sparkman, 2012, p. 21; Singh, 2007, p. 59).

Two writers credited with coining the term 'emotional intelligence', Salovey \& Mayer (1990, p. 189) describe emotional intelligence as "a form of social intelligence that involves the ability to monitor one's own and others' feelings and emotions, to discriminate among them, and to use this information to guide one's own thinking and actions". EI is, therefore, used to describe qualities like "understanding one's own feelings, empathy for the feelings of others and the individual's ability to regulate his or other people's emotion in a way that enhances living" (Ugwu, 2011, p. 137). Singh (2013, p. 334) defines EI as an array of non-cognitive capabilities, competencies, and skills that influence one's ability to succeed in coping with environmental demands and pressures.

\subsection{Servant leadership and emotional intelli-} gence. There is insufficient literature and research linking servant leadership and emotional intelligence. Winston \& Hartsfield (2004, p. 1) offer, perhaps, the most revealing, although not convincing link between servant leadership models and emotional intelligence. They compared Mayer \& Salovey (1997)'s abilities dimensions: (a) the ability to appraise and express emotion; (b) the use of emotion to enhance cognitive processes and decision making; (c) the ability to understand and analyze emotions; and (d) the reflective regulation of emotion, with five servant leadership models, namely: Page \& Wong (2000), Patterson (2003), Russel \& Stone (2002) Sendjaya \& Sarros (2002) and Winston's SL Model (2003), and observed strong ties between SL and the EI dimensions (a), (b) and (d), but not much correlation with dimension (c). Winston \& Hartsfield (2004) caution that there is a lack of clarity on whether emotional intelligence is particularly tied to servant leadership or just leadership, in general, but that the established similarities require researchers and leadership development practitioners to consider the role of emotional intelligence in servant leadership.

\section{Methodology}

The study was conducted using the mixed methods research (MMR) triangulation design combining quantitative and qualitative data collection and data analysis and integration of findings. In seeking to reconcile the paradigm wars between pure postpositivism, which informs quantitative research design and constructionism-interpretivism which informs qualitative research, advocates of the MMR adopted pragmatism as the philosophical foundation for the mixed methods research approach (Johnson 
\& Onwuegbuzie, 2004, p. 16; Migiro \& Magangi, 2011, p. 3758). Pragmatism is perceived as flexible research which allows for triangulation of research results by combining quantitative (deductive) and qualitative (inductive) research designs (Migiro \& Magangi, 2011, p. 3759). Mixed methods research is a research methodology that involves collecting, analyzing and interpreting quantitative and qualitative data in a single study or in a series of studies in order to investigate the same underlying phenomenon (Leech \& Onwuegbuzie, 2009, p. 267). Teddlie $\&$ Tashakkori (2006, p. 15) proffered this definition: "mixed methods research is defined as research in which the investigator collects and analyzes data, integrates the findings, and draws inferences using both qualitative and quantitative approaches or methods in a single study or program of enquiry".

The primary purpose of using a concurrent triangulation design is to obtain confirmation, disconfirming, corroboration or cross-validation within a single research study (Terrell, 2012, p. 268; Stentz, Plano Clark \& Matkin, 2012, p. 1175; Creswell, 2009, p. 213). An illustration of the mixed methods triangulation design is provided in Figure 1 below:

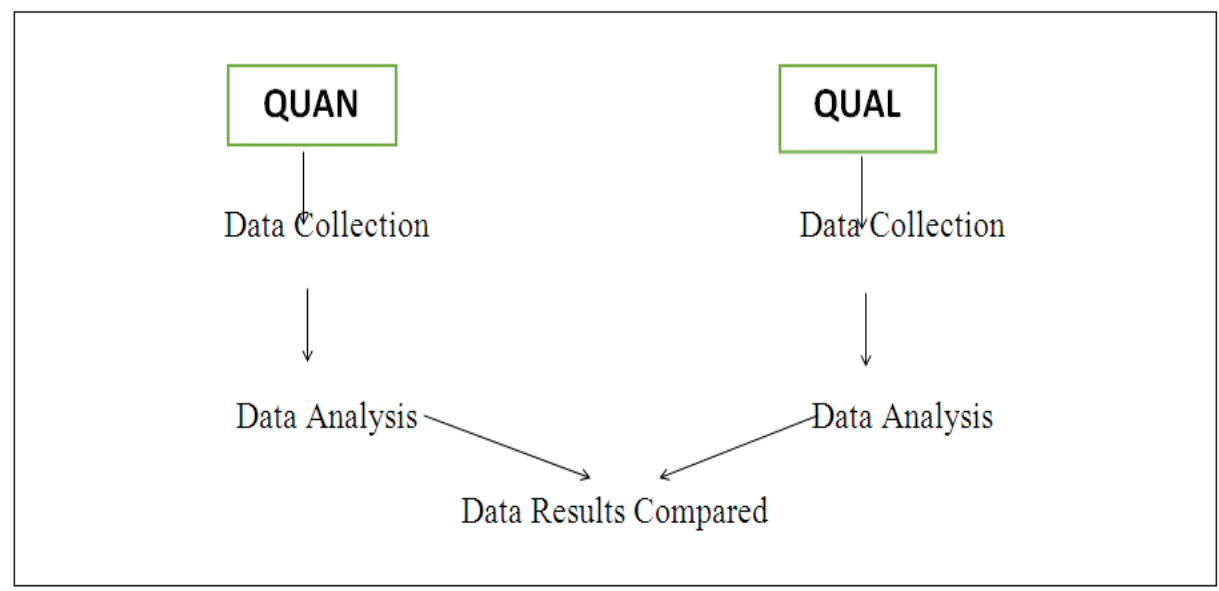

Source: adapted from Cresswell et al. (2009, p. 210).

Fig. 1. The mixed method concurrent triangulation design

This research work adopted the mixed methods, concurrent triangulation design which comprised the use of both quantitative and qualitative designs with equal priority (QUAL+QUAN) and the data were integrated at the analysis and interpretation phases.

2.1. Research assumptions. In undertaking the study, the researcher made specific underlying assumptions regarding the research units and the research context, namely:

- There are various management and leadership skills development programs conducted in the commercial banking sector for its different levels of managerial staff. One of the banks' staff manual outlines the programs conducted in the bank, including managerial leadership development programs. The researcher assumed that all other banks provide some form of leadership development programs for their managers.

- Managerial staff in the commercial banking sector have a relatively high level of educational background to understand the various leadership concepts, theories and models that they get exposed to through continuous professional development.

- The performance of managerial leaders in the sector is largely based on financial measures such as profit before taxation, cost/income ratios, revenues, non-performing loans, and liquidity ratios among others, and, ultimately, profits or losses after tax. However, there is acknowledgement of the role of non-financial performance measures in contributing to the achievement of financial targets.

Qualitative performance measures play a critical part in shaping the viability and performance of all organizations and if they are not adequately attended to, they can have a negative impact on quantifiable performance measures.

2.2. The aim of the paper. The research study sought to address the following strategic research aim:

To establish the role of servant leadership and emotional intelligence in the development of leadership soft skills and competences and the impact of such skills/competencies on the performance of managerial leadership within the commercial banking sector in Zimbabwe.

2.3. Research hypotheses. In order to answer the strategic research question, the study sought to address the following research hypotheses. 
2.3.1. Research hypothesis $1 . H_{0}$ : There are no specific leadership skills and competencies derived from servant leadership and emotional intelligence training for managers.

$H_{A}$ : There are specific leadership skills and competencies derived from servant leadership and emotional intelligence training for managers.

2.3.2. Research hypothesis 2. $H_{0}$ : There is no relationship between servant leadership attributes and emotional intelligence and selected non-financial deliverables for managers.

$H_{A}$ : There is a relationship between servant leadership attributes and emotional intelligence and selected non-financial deliverables for managers.

2.3.3. Research hypothesis 3. $H_{0}$ : An integrated servant leadership and emotional intelligence development program does not enhance managerial performance in a commercial banking sector.

$H_{A}$ : An integrated servant leadership and emotional intelligence development program enhances managerial performance in a commercial banking sector.

2.4. Target population, sample size and data collection. The commercial banking sector in Zimbabwe comprising 15 banks had a population of 1270 managerial staff out of whom 600 were in middle, senior and executive management who constituted the target population (Bankers Association of Zimbabwe, 2014). For quantitative data collection, a sample size of 234 was determined at $95 \%$ confidence level and 5\% margin of error or confidence interval with a $50 \%$ response rate (Redhill Group, 2014; Raosoft, (2014). The sample size was increased to 430 to cater for nonresponses and to cater for non-usable responses and possible low response rate often associated with mailed questionnaires (De Vaus, 2014, p. 125). For qualitative data collection, a purposive sample size of eight interviewees drawn from six commercial banks was used. They comprised one chief executive officer of a financial holding company, two heads of human capital, three heads of core banking departments, one head of risk management and one senior compliance manager. The participants were interviewed using a structured interview guide, and the data were collected using a multimedia device. The responses were transcribed into text for analysis.

2.5. Reliability and validity. A survey questionnaire was designed, pilot tested, refined and distributed to the 430 sample group in 14 participating banks using the stratified sampling method to ensure responses were obtained from each bank. The questionnaire comprised questions addressing demographic characteristics of the respondents and Likert type questions on servant leadership and emotional intelligence as sepa- rate constructs and combined. To determine the reliability of the 144 items in the research instrument that was used in this study, the Cronbach's Alpha coefficient was computed as 0.869 which meets the minimum measure of consistency in the results.

2.6. Research limitations. The research study was cross-sectional in nature made over a limited period of time and confined to one geographical area, the capital city Harare. The researcher was constrained by time and financial resources normally required to undertake a research of a bigger magnitude over a long period of time.

\section{Presentation and data analysis}

For quantitative data, 211 usable questionnaires were returned and the data were collated, captured, cleaned and analyzed using the Statistical Package for Social Sciences (SPSS) version 22.0, while qualitative text data from the eight informants were summarized into thematic codes using the NVIVO software package version 10 . The analysis of demographic data (gender, age, qualifications, managerial level, years of experience, number of leadership courses attended, servant leadership and emotional intelligence courses attended) was done using descriptive statistical analysis comprising frequencies, measures of central tendency (mean, median and mode) and measures of dispersion (range and standard deviation). Inferential statistical analytical tools such as Pearson Chi-squire, Fisher's exact, OneSample Binomial, Wilcoxon signed ranks, and Friedman tests. One sample t-test, one way ANOVA and Factor analyses were also used in measuring the relationships between demographic characteristics (see Appendix 1)

3.1. Results of study. This section highlights the main results arising from the study, the contributions of the researcher and selected recommendations that can be implemented to ensure that the outcomes of the study benefit the research community and managerial staff in the commercial banking sector and other sectors in Zimbabwe and beyond.

3.2. Research findings. The findings showed that there are low levels of understanding of SL and EI, that leadership skills and competencies from SL and EI were below minimum levels and that banks needed to do more to expose their managers to these soft skills. Further, results showed that there are specific soft skills and competencies that can be derived from exposing bank managers to SL and EI. The findings showed that servant leadership and emotional intelligence add value to the execution of leadership responsibilities and achievement of deliverables. The findings also showed that servant leadership and emotional intelligence derived skills have a place in the competence development of managerial leaders and, conse- 
quently, in enhancing leadership performance in the banking sector. Qualitative findings corroborated the complementary nature of the two constructs as they help to build soft skills like influencing ability and relationship management competencies. Leaders endowed with SL and EI competencies were more able to harness the energies of their teams towards attainment of the vision, and create high trust and integrity between leaders and their teams. Qualitative findings on the possibility of integrating SL attributes and EI competencies showed that interviewees perceived such factors as social awareness, influencing and persuasion skills, role modelling, stakeholder relationship management and team orientation as being common to both SL and EI.

Performance factors that were impacted the most by both SL and EI were more bank value creation, productive organizational culture and improved employee engagement. The least impacted by both constructs were more community involvement and high customer retention, although the frequencies were above $55 \%$. There is a contradiction inherent in these findings in that logic would have reasoned that the combined impact of SL and EI would enhance their impact on more community involvement and more customer retention. It does appear that the combined ingredients of SL and EI shift focus and impact to employees, organizational culture and value creation.

3.3. Contributions/implications of the study. Based on the identified gaps the researcher made some contributions which could add value to the research community and professional managerial leaders in the commercial banking sector in Zimbabwe. The researcher juxtaposed what he considered to be complementary EI and SL four categories of competencies, as illustrated below in Table 1 .

The first category of EI intrapersonal competencies and SL internal components was collectively named
SL/EI integrated intrinsic competencies. These are skills and behaviors which define a leader's ability to understand who they are as a leader, the ability to be self-conscious of what they stand for as a leader and how they prepare themselves before meeting with followers, peers and superiors within the organization.

The EI self-management components and SL selfregulatory components were integrated into what the researcher termed SL/EI leader-centric competencies which collectively create the leaders' ability and willingness to regulate or manage their leadership behaviors in such a way that they will be viewed positively as leaders when the process of engaging others is operationalized.

The EI social awareness and SL environmental awareness components were integrated into what has been termed, SL/EI leader-diagnostic competencies. These competencies enable leaders to read through, perceive, discern and distil the state of those that they are interacting with face to face, online or through other communication methods.

The last category of EI interpersonal relationship and SL stakeholder management components were integrated into SL/EI leader value-adding competencies. Leaders use these competencies to articulate vision and strategy to all stakeholders, to manage conflict and heal relationships, use persuasion and influencing skills to harness the energies of teams and to collaborate with all stakeholders as well, as protect company assets for future generations.

The researcher posits another view that SL and EI competence levels can be classified into a mix of four quadrants with each mix creating implications for the type of leadership and level of performance outcomes. This is illustrated in Figure 2.

Table 1. Proposed integration of emotional intelligence and servant leadership skills

\begin{tabular}{|l|l|}
\hline \multicolumn{1}{|c|}{ Emotional intelligence competencies } & \multicolumn{1}{c|}{ Servant leadership competencies } \\
\hline Emotional self-awareness & \multicolumn{1}{c|}{ Servaler internal components } \\
\hline Accurate self-assessment & Self-awareness \\
\hline Assertiveness & Foresight and visioning \\
\hline Self-regard/self-confidence & Conceptualization \\
\hline Self-actualization & Commitment \\
\hline Independence/feelings/thoughts & Servant hood/calling \\
\hline Initiative and trustworthy & Visioning/voluntary Subordination \\
\hline Achievement drive & Transcendental spirituality \\
\hline Self-management components & Self-identity \\
\hline Emotional self control/impulse control/confidence & Servant leadership self-regulatory components \\
\hline Feelings/thoughts & Credibility/moral-ethical behavior \\
\hline Trustworthiness & Honesty/integrity \\
\hline Conscientiousness & Humility/authentic self \\
\hline Adaptability/flexibility & Trust \\
\hline Achievement drive & Modelling \\
\hline
\end{tabular}


Table 1 (cont.). Proposed integration of emotional intelligence and servant leadership skills

\begin{tabular}{|l|l|}
\hline \multicolumn{1}{|c|}{ Emotional intelligence competencies } & \multicolumn{1}{|c|}{ Servant leadership competencies } \\
\hline Initiative/problem solving & Building capacity for reciprocity \\
\hline Stress tolerance/managing anxiety & Servant leadership environmental awareness components \\
\hline Happiness/optimism & Listening/standing back \\
\hline Social awareness & Empathy/covenantal relationships \\
\hline Empathy & Service/responsible Morality \\
\hline Service orientation & Appreciation of others \\
\hline Interpersonal relations & Altruism/valuing people \\
\hline Organizational awareness & Egalitarianism/Servant hood \\
\hline & Inspirational/Agapao \\
\hline & Interpersonal Acceptance \\
\hline Interpersonal relationship management & Servant Leadership Stakeholder Management Components \\
\hline Developing others & Vision/foresight/persuasive mapping/goal-setting \\
\hline Influence/change catalyst & Healing relationships \\
\hline Communication & Influence and persuasion \\
\hline Conflict management & Transforming influence \\
\hline Visionary leadership & Pioneering and pacesetting \\
\hline Catalyzing leadership & Organizational stewardship \\
\hline Building bonds & Delegation/empowerment \\
\hline Team building/team working & Commitment to the growth of people/inspirational \\
\hline Collaboration & Sharing leadership/shared decision making/team building \\
\hline Interpersonal relations & Building community/creating value for community \\
\hline Social responsibility & Accountability \\
\hline & \\
\hline
\end{tabular}

\section{SERVANT LEADERSHIP/EMOTIONAL INTELLIGENCE MODEL}

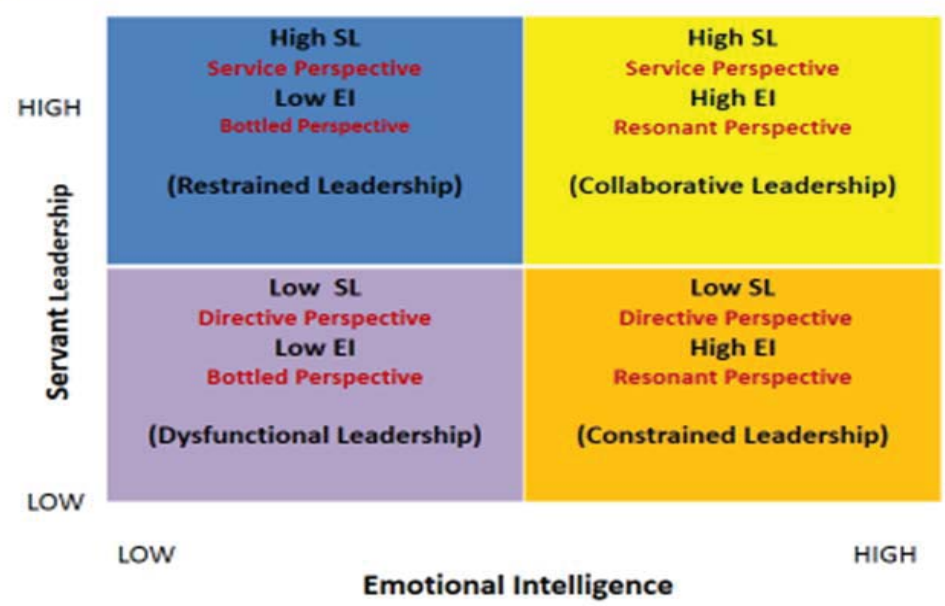

Fig. 2. Integrated SL/EI-lead impact model

Each quadrant represents a certain mix of SL and EI to collectively create what the researcher has termed the integrated servant leadership and emotional intelligence leadership impact model (SL/EI-LEAD MODEL). The model forms part of the leadership soft skills development program on SL and EI for bank managers. The quadrants create four types of leadership behavioral domains.

- Dysfunctional leadership: this quadrant is characterized by low servant leadership and emotional intelligence competencies. As a result, leaders in this category care less about follower needs, respond and interact in an insensitive manner to stakeholders and tend not to realize the importance of building productive relationships. They do not worry much about service to internal and external customers. Consequently, their leadership is dysfunctional and they fail to achieve set goals.

- Restrained leadership: leaders in this quadrant have high servant leadership, but low emotional intelligence and, as a result, they display many SL competencies, but lack emotional intelligence to resonate with followers, peers, superiors and others. They show restrained behaviors which incapacitate them from building productive value-adding relationships. They show a lot 
of restraint, do not reach out and fail to create the necessary chemistry with their role contacts, the people they should interact and work with in order to achieve their goals. The researcher argues that these leaders can be perceived as passive-submissive and, therefore, fail to manage relationships. Low emotional intelligence exhibits what the researcher calls bottled emotional maturity, and such leaders fail to use their rational mind to inform and regulate their emotions, the researcher argues. The low level of emotional intelligence inhibits the full exploitation of the high servant leadership attributes.

- Constrained leadership: leaders in this quadrant display low servant leadership, although their emotional intelligence is high. They constrain themselves by not showing behaviors like service orientation, conceptualization, ethicalmoral behaviors. They do not act credibly all the time and may lack integrity while also caring less about the needs of others. They are constrained in that if they applied a wide array of SL behaviors, they would be able to focus a lot more on the stakeholder needs and achieve more. Low servant leadership manifests more in directive behaviors, like making most of the decisions, telling others what to do and how to do it and less of shared leadership. The leader may be displaying high emotional intelligence, but more for the ultimate benefit of the leader's needs than those of others.

- Collaborative leadership: leaders in this quadrant display high servant leadership and high emotional intelligence. They exhibit what the researcher calls collaborative leadership. They encompass the best of SL and EI and reach out with a service mindset, humble, but focused and determined, assertive, but empathetic, and create business alliances and networks which they utilize to optimum advantage and become high achievers in their leadership roles. They understand the emotional state and the needs of others, share leadership with followers, take an active and keen interest in providing quality leadership in order for their teams to provide quality service to customers. They are conscious of the need to act with credibility, integrity and within good corporate governance standards and show responsible stewardship to the organization and to the community. They seek to ensure their institutions are perceived as good corporate citizens and they, therefore, resonate with their surroundings. The leader exploits to the full the potential utility of high servant leader and emotional intelligence competencies for the mutual benefit of all stakeholders including the leader himself or herself. This is the high impact leader performance zone that leaders should be striving to reach.

The quest for the right mix which is acquisition, application and practicing high levels of SL and EI is a relentless pursuit and, therefore, it is possible for a leader to regress from the ideal level to any of the other quadrants. It requires constant and continuous feedback, discussions, workshops and refresher programs to enhance the use of these competencies.

3.3.1. Methodological contributions. Literature on mixed methods research (MMR) points towards the complexities and difficulties often encountered in undertaking research which requires a researcher to be au fait with both quantitative and qualitative research designs and, furthermore, to be conversant with the various research designs under MMR. The researcher considers this research to be ground breaking in the banking sector in Zimbabwe in that despite the time, effort and cost often associated with mixed methods research, especially the concurrent design which require data collection, collation, transcribing and analysis simultaneously, the researcher was able to conduct and complete the study. The researcher took the intellectual courage to research two constructs SL and EI using mixed methods concurrent design. It takes intellectual courage and optimism to undertake such research. The researcher posits that with this study he has made a modest methodological contribution which should also benefit the research community.

3.3.2. Empirical contributions. A review of studies undertaken in the banking sector did not point to evidence of a study of both SL and EI in the sector, let alone the whole Zimbabwean economy. The researcher was able to conduct this empirical study and the findings of this research work are testimony to the contextual and empirical contribution to research practice.

\section{Recommendations}

The researcher offers the following recommendations in order that various groups of people can benefit from this study and its contributions.

- Sharing research findings with participants: distribution of major research findings is considered an ethical research practice and custom which is encouraged to enable research participants and gatekeepers to benefit from the research findings. The researcher proposes to distribute an abridged user friendly version of the study findings to the gatekeepers the Reserve Bank of Zimbabwe and the Bankers Association of Zimbabwe and to the chief executive officers of the banks that participated in the research 
study subject to securing permission from KwaZulu-Natal University which has copyright for this thesis.

- Full program development: the prototype program development above forms the basis for the development of a full-fledged learning and development program encompassing all the competences and the model to ensure that workshops are conducted for managerial staff with case studies, role plays and syndicate groups to facilitate learning and internalization of the attributes and skills of SL and EI. A trial workshop should be conducted from which feedback secured could be used to refine the program before launching it on a wider scale in the bank where the researcher currently works.

The researcher is convinced that adoption of a multiplicity of awareness and publicity learning strategies will grasp the attention of a core group of managers which can form the nucleus for the dispersal of servant leadership and emotional intelligence benefits to managerial staff.

\section{Research limitations}

Hofstee (2009, p. 117) argues that all research methods have limitations and it is, therefore, necessary to state the most important limitations that affect the reliability of the findings or the extent to which findings can be generalized (Hofstee, 2009, p. 118). The data collection process was confined to the samples drawn from Harare, the capital city, only although the commercial banks operate in various cities and towns countrywide. One of the reasons why this strategy was adopted was due to the location of the head offices of all the banks that participated. The head offices are all located in Harare where the decisionmakers are located. With the researcher also working in a head office of one of the banks, it was easier to access the people who control the levers of decision making. The other limitations for concentrating the research in the capital city were due to issues of time and costs. A cross-sectional research by its very nature is limited in terms of time frame. To collect data countrywide would have required strong logistical support and additional finances.

From a quantitative data collection view, the researcher was limited in accessing the respondents directly, more so given the confidentiality factor associated with banking activities. Consequently, the researcher had to rely on contact persons in the $\mathrm{Hu}-$ man Capital Units of the participating banks. In as much as the contact persons were fully briefed about how they were expected to distribute the questionnaires, the variations in the response rate point to the lack of uniformity, level of commitment and or per- haps challenges experienced by the contact persons in the collection of the instruments. The positive side of this was that respondents and nonrespondents were not identifiable.

Conducting a research study using concurrent MMR design is taxing from time, effort and energy point of view. The researcher had to find some balance between attending to the demands of printing, packaging, distribution and collection of questionnaires while also arranging and conducting qualitative interviews in addition to attending to normal working life. Consequently, this could have limited the scope of the qualitative interview coverage.

The response rate for retention of questionnaires could have been adversely affected by timing of data collection, which was conducted during the business peak period of the year, October to December 2014 when most people within the chosen target group take leave to go on holidays. Furthermore, during the first two months of a year, banking business in Zimbabwe is often slow in peaking and again, from experience, a number of staff take leave during that period. This timing dynamic could have contributed to low response rate from some of the banks.

For qualitative data collection, being able to pin down and interview the eight informants took a lot of effort, persuasion and assurances given that the researcher works in a bank and accessing senior and executive leaders in competitor banks was perceived with fear of retribution from superiors and not wanting to be seen as perhaps sharing confidential and sensitive competitor information. It was only possible after holding preliminary discussions and explaining the nature of the research and the delimitations. While limitations and constraints were encountered, they did not compromize the reliability of the quantitative responses or the quality of the interview outcomes.

\section{Further directions for study}

There is a scope for further research on the comparative impact and effect of servant leadership and emotional intelligence on executive leadership in other banking and financial institutions in other African countries in order to develop standardized SL and EI leadership competencies for executives and directors to improve banking inclusiveness in Africa.

There is a need to explore why most of the countries in Africa are still unbanked and how staff in African banks can play their part to improve uptake in use of banks and financial institutions on the continent.

\section{Conclusions}

The purpose of this research was to establish the role played by the constructs of servant leadership and 
emotional intelligence in developing managerial leadership competencies in order to enhance managerial performance in a commercial banking sector in Zimbabwe. A cross-sectional research study was undertaken using the concurrent mixed methods design. The results of the study showed that servant leadership and emotional intelligence attributes can play a significant role in building managerial leadership competencies that can enhance managerial performance in areas such as articulating vision and strategy, building and sustaining productive organizational culture, devel- opment and retention of talent, enhancing employee engagement, improving stakeholder relationship management, retaining bank customers, promotion of diversity, value creation and community involvement. Improved performance in these areas can help to enhance organizational performance in quantitative measures such as revenue, cost income ratio, return on equity and profitability. A SL and EI leadership development model was designed from the findings of this study and its implementation could assist in addressing the research problem and research aim.

\section{References}

1. Abdul, L.A. \& Ehiobuche, C. (2011). Emotional intelligence and managerial competence. Insights to a Changing World, 4, pp. 41-58.

2. Anand, R. \& UdayaSuriyan, G., (2010). Emotional Intelligence and Its Relationship with Leadership Practices. International Journal of Business and Management, 5 (2), pp. 65-76.

3. Anderson, J.A. (2009). When a servant leader comes knocking..., Leadership \& Organizational Development Journal, 30 (1), pp. 4-15.

4. Bankers Association of Zimbabwe Report. (2015). 1-2 Beigi, M. \& Shirmohammadi, M. (2011). Effects of an emotional intelligence training program on service quality of bank branches, Managing Service Quality, 21 (5), pp. $552-567$.

5. Boone, L.W. \& Makhani, S. (2012). Five necessary attitudes of a servant leader, Review of Business, 33 (1), pp. 83-96.

6. Creswell, J.W. (2009). Research design: Qualitative, quantitative, and mixed methods approaches ( $3^{\mathrm{rd}}$ Ed.). Thousand Oaks: Sage.

7. De Vaus, D. (2013). Surveys in social research. London: Routledge.

8. Emmerling, R.J. \& Boyatzis, R.E. (2012). Emotional and social intelligence competencies: cross cultural implications, Cross Cultural Management, 19 (1), pp. 4-18.

9. Flint, B.B. (2011). The journey to competitive advantage through servant leadership. Bloomington: WestBow Press.

10. Focht, A. and Ponton, M. (2015). Identifying primary characteristics of servant leadership: Delphi study, International Journal of Leadership Studies, 9 (1), pp.1-18.

11. Goleman, D. (2001). Emotional intelligence: issues in paradigm building, The Emotionally Intelligent Workplace, 13 (26).

12. Hannay, M. \& Fretwell, C. (2010). Who will be a servant leader? Those with high emotional intelligence step forward! In Academic and Business Research Institute Conference. Las Vegas, NV.

13. Hofstee, E. (2009). Constructing a good dissertation. Sandton, EPE.

14. Hunter, J.C. (2012). The servant: A simple story about the true essence of leadership. New York: Crown Business Group.

15. Johnson, R.B. \& Onwuegbuzie, A.J. (2004). Mixed methods research: a research paradigm whose time has come, Educational Researcher, 33 (7), pp. 14-26.

16. Khalili, M.A., (2013). Relationship between emotional intelligence \& leadership style, International Journal of Management Research and Review, 3 (4), pp. 2689-2702.

17. Klare, D., Behney, M. \& Ferrer Kenny, B. (2014). Emotional intelligence in a stupid world, Library Hi Tech News, 31 (6), pp. 21-24.

18. Laub, J.A. (1999). Assessing the servant organization: Development of the servant organizational leadership assessment (SOLA). instrument. Florida Atlantic University; 01119.

19. Leech, N.L. \& Onwuegbuzie, A.J. (2009). A typology of mixed methods research designs, Qual Quant, 43, pp. 265-275.

20. Maulding, W.S., Peters, G.B., Roberts, J., Leonard, E. \& Sparkman, L. (2012). Emotional intelligence and resilience as predictors of leadership in school administrators. Journal of Leadership Studies, 5 (4), pp. 20-29.

21. McClellan, J.L. (2007). The advisor as servant: the theoretical and philosophical relevance of servant leadership to academic advising, NACAD, 27 (2), pp. 41-49.

22. Melchar, D.E. \& Bosco, S.M. (2010). Achieving high organization performance through servant leadership. Journal of Business Inquiry, 9 (1), pp. 74-88.

23. Migiro, S.O. \& Magangi, B.A. (2011). Mixed methods: a review of literature and the future of the new research paradigm. African Journal of Business Management, 5 (10), pp. 3757-3764.

24. Obradovic, V., Jovanovic, P., Petrovic, D., Mihic, M. \& Mitrovic, Z., (2013). Project managers' emotional intelligence - a ticket to success, Periodica-Social Behavioral Sciences, 74, pp. 274-284. 
25. Parris, D.L. \& Peachey, J.W. (2013). A systematic literature review of servant leadership theory in organizational contexts, Journal of Business Ethics, 113, pp. 377-393.

26. Paroline, J.L. (2005). Investigating the Relationship among Emotional Intelligence, Servant Leadership Behaviors and Servant Leadership Culture. Servant Leadership Roundtable. Regent University.

27. Patterson, K.A. (2003). Servant leadership: A theoretical model. Doctoral dissertation, Regent University (UMI No. 3082719).

28. Prins, A., van Niekerk, E. \& Weyers, A. (2011). Emotional intelligence: tipping point in workplace excellence. Randburg: Knowles Publishing.

29. Rachmawati, A.W. \& Lantu, D.C. (2014). Servant leadership theory development \& measurement, Social and Behavioral Sciences, 115, pp. 387-393.

30. Raosoft. (2014). Sample size calculator [online]. Available at: <http://www.raosoft.co./samplesize.html> [Accessed 4 January 2014].

31. Redhill Group. (2014). Sample size calculator [online]. Available at: <http://www.redhillgroup.co./researchtoolkit/sample-size-calculator/> [Accessed 4 January 2014].

32. Reed, L.L., Vidaver-Cohen, D. \& Coldwell, R.S. (2011). A new scale to measure executive servant leadership: development, analysis, and implications for research, Journal of Business Ethics, 101, pp. 415-434.

33. Russell, R. \& Stone, A.G. (2002). A review of servant leadership attributes: developing a practical model, Leadership \& Organization Development Journal, 23 (3), pp. 145-157.

34. Russell, R.F. (2001). The role values in servant leadership, Leadership \& Organizational Development Journal, 22 (2), pp. 76-84.

35. Salovey, P. \& Mayer, J.D. (1990). Emotional Intelligence, Imagination, cognition and personality, 9 (3), pp. 185-211.

36. Sendjaya, S., Sarros, J.C. \& Santora, J.C. (2008). Defining and measuring servant leadership behavior in organizations, Management Studies, 45 (2), pp. 402-424.

37. Senjaya, S. \& Perketi, A. (2010). Servant leadership as antecedent of trust in organizations, Leadership and Organization Development, 31 (7).

38. Shekari, H. \& Nikooparvar, M.Z. (2012). Promoting leadership effectiveness in organizations: a case study on the involved factors of servant leadership, International Journal of Business Administration, 3 (1), pp. 54-65.

39. Singh, P. (2013). Symbiotic relationship between emotional intelligence and collegial leadership, International Business \& Economics Research Journal, 12 (3), pp. 331-344.

40. Singh, S.K. (2007). Role of emotional intelligence in organizational learning: an empirical study, Singapore Management Review, 29 (2), pp. 55-74.

41. Spears, L.C. (2010). Character and servant leadership: ten characteristics of effective, caring leaders, Journal of Virtues \& Leadership, 1 (1), pp. 25-30.

42. Stentz, J.E., Plano Clark, V.L. \& Matkin, G.S. (2012). Applying mixed methods to leadership research: A review of current practices, The Leadership Quarterly, 23, pp. 1173-1183.

43. Tavakol, M. \& Dennick, R. (2011). Making sense of Cronbach's alpha, International Journal of Medical Education, 2, pp. 53-55.

44. Teddlie, C. \& Tashakkori, A. (2006). A general typology of research designs featuring mixed methods, Research in the Schools, 13 (1), pp. 12-28.

45. Terrell, S.R. (2012). Mixed-methods research methodologies, The Qualitative Report, 17 (1), pp. $254-280$.

46. Turner, R. \& Lloyd-Walker, B. (2008). Emotional intelligence (EI) capabilities training: can it develop EI in project teams? Int. Journal of Managing Projects in Business, 1 (4), pp. 512-534.

47. Ugwu, L.I. (2011). Emotional and general intelligence: meeting points and missing points, Asian Social Science, 7 (7), pp. 137-140.

48. Van Dierendonck, D. \& Nuijten, I. (2011). The servant leadership survey: development and validation of a multidimensional measure, Journal of Business Psychology, 26, pp. 249-267.

49. Winston, B.E. \& Hartsfield, M. (2004). Similarities between emotional intelligence and servant leadership. Research Roundtable: Regent University.

50. Wong, P.T.P. \& Davey, D. (2007). Best practices in servant leadership. Servant Leadership Roundtable. School of Global Leadership \& Entrepreneurship, Regent University.

Appendix 1. Inferential statistical analysis tables

The selected tables highlight a sample of the inferential statistical analyses conducted in respect of the research work.

Relationship between servant leadership and emotional intelligence training

The Fisher 's Exact Test in Table 2 below was conducted to determine the relationship between servant leadership and emotional intelligence and whether in attending a course on servant leadership there was a likelihood that managers would also learn aspects of emotional intelligence. 
Table 1. Fisher's Exact Test

\begin{tabular}{|c|c|c|c|c|c|}
\hline & Value & df & Asymp. Sig. (2-sided) & Exact sig. (2-sided) & Exact sig. (1-sided) \\
\hline Pearson Chi-square & $15.603^{\mathrm{a}}$ & 1 & .000 & & \\
\hline Continuity Correction ${ }^{b}$ & 14.387 & 1 & .000 & & \\
\hline Likelihood Ratio & 15.745 & 1 & .000 & & \\
\hline Fisher's Exact Test & & & & .000 & .000 \\
\hline Linear-by-Linear Association & 15.528 & 1 & .000 & & \\
\hline $\mathrm{N}$ of valid cases & 207 & & & & \\
\hline \multicolumn{6}{|c|}{ a. 0 cells $(0.0 \%)$ have an expected count of less than 5 . The minimum expected count is 25.43 . } \\
\hline b. Computed only for a $2 \times 2$ tab & & & & & \\
\hline
\end{tabular}

From the above analysis, the $p$-value for the Fisher's Exact Test was seen to be 0.000 , and being less than the critical value of 0.05 (Weisstein, n.p.) the conclusion was that receiving training in servant leadership was highly dependent on receiving training on emotional intelligence. In other words, there was a greater likelihood of one not having received training in servant leadership if that person had not yet received training in emotional intelligence and vice versa.

The results of the Fisher's Exact Test suggest the existence of a relationship in the attributes of servant leadership and dimensions of emotional intelligence.

\section{Relationship between demographic data and awareness of servant leadership}

The One-Way ANOVA analysis was computed to determine if there was association between demographic data from the 211 respondents and their awareness of the construct of servant leadership and the results, as shown in Table 3 below.

Table 3. ANOVA analysis - servant leadership awareness

\begin{tabular}{|c|c|c|c|c|c|c|}
\hline & & $\begin{array}{l}\text { Sum of } \\
\text { squares }\end{array}$ & df & $\begin{array}{l}\text { Mean } \\
\text { square }\end{array}$ & $\mathrm{F}$ & Sig. \\
\hline \multirow{3}{*}{ Gender } & Between groups & 1.577 & 4 & .394 & 1.883 & .115 \\
\hline & Within groups & 42.919 & 205 & .209 & & \\
\hline & Total & 44.495 & 209 & & & \\
\hline \multirow{3}{*}{ Age range } & Between groups & 1.641 & 4 & .410 & .701 & .592 \\
\hline & Within groups & 119.355 & 204 & .585 & & \\
\hline & Total & 120.995 & 208 & & & \\
\hline \multirow{3}{*}{ Highest educational qualification } & Between groups & 4.640 & 4 & 1.160 & 2.081 & .085 \\
\hline & Within groups & 113.704 & 204 & .557 & & \\
\hline & Total & 118.344 & 208 & & & \\
\hline \multirow{3}{*}{ Managerial level } & Between groups & 7.863 & 4 & 1.966 & 2.745 & .030 \\
\hline & Within groups & 145.401 & 203 & .716 & & \\
\hline & Total & 153.264 & 207 & & & \\
\hline \multirow{3}{*}{$\begin{array}{l}\text { Number of years of working in the bank- } \\
\text { ing sector }\end{array}$} & Between groups & 15.034 & 4 & 3.759 & 1.993 & .097 \\
\hline & Within groups & 382.889 & 203 & 1.886 & & \\
\hline & Total & 397.923 & 207 & & & \\
\hline \multirow{3}{*}{$\begin{array}{l}\text { Years of experience in a managerial } \\
\text { position in the banking sector }\end{array}$} & Between groups & 13.724 & 4 & 3.431 & 2.395 & .052 \\
\hline & Within groups & 292.257 & 204 & 1.433 & & \\
\hline & Total & 305.981 & 208 & & & \\
\hline \multirow{3}{*}{$\begin{array}{l}\text { Attending leadership development } \\
\text { courses in the banking sector }\end{array}$} & Between groups & .995 & 4 & .249 & 2.243 & .066 \\
\hline & Within groups & 22.501 & 203 & 1111 & & \\
\hline & Total & 23.495 & 207 & & & \\
\hline \multirow{3}{*}{ Number of leadership courses attended } & Between groups & 7.498 & 4 & 1.875 & 2.731 & .031 \\
\hline & Within groups & 122.185 & 178 & .686 & & \\
\hline & Total & 129.683 & 182 & & & \\
\hline \multirow{3}{*}{ Attended a course on servant leadership } & Between groups & 8.695 & 4 & 2.174 & 13.894 & .000 \\
\hline & Within groups & 31.761 & 203 & .156 & & \\
\hline & Total & 40.457 & 207 & & & \\
\hline \multirow{3}{*}{$\begin{array}{l}\text { Attended a course on emotional intelli- } \\
\text { gence }\end{array}$} & Between groups & 3.207 & 4 & .802 & 3.367 & .011 \\
\hline & Within groups & 48.107 & 202 & .238 & & \\
\hline & Total & 51.314 & 206 & & & \\
\hline
\end{tabular}

In evaluating the $p$-values in Table 3 above, with least being 0.000 , the most accurate determinant of the self-rated level of awareness of servant leadership was whether the respondents had attended a course on servant leadership. 
Again, the relatively low $p$-value of 0.011 , identified with the variable, attended a course on emotional intelligence cross-validates the established finding that receiving training in servant leadership was highly dependent on receiving training on emotional intelligence.

\section{Relationship between managerial level and knowledge of servant leadership}

The One-Sample Binomial Test was computed to determine if there was any relationship between managerial level of respondents and their awareness of servant leadership and the results are stated in Figure 2 below.

Hypothesis Test: One-Sample Binomial Test

Significance Level: $\quad 95 \%(p=0.05)$

Rejection Criteria: $\quad$ Reject $H_{0}$ if $p \leq 0.05$; Accept $H_{0}$ if $p>0.05$

The results of the analysis are presented in Figure 3 below:

Hypothesis Test Summary

\begin{tabular}{|c|c|c|c|c|}
\hline & Null Hypothesis & Test & Sig. & Decision \\
\hline 1 & $\begin{array}{l}\text { The categories defined by The } \\
\text { higher the managerial level, the } \\
\text { more likely that one will know about } \\
\text { servant leadership = Agree and } \\
\text { Disagree occur with probabilities } \\
0.5 \text { and } 0.5 \text {. }\end{array}$ & $\begin{array}{l}\text { One-Sample } \\
\text { Binomial } \\
\text { Test }\end{array}$ & .890 & $\begin{array}{l}\text { Retain the } \\
\text { null } \\
\text { hypothesis. }\end{array}$ \\
\hline
\end{tabular}

Asymptotic significances are displayed. The significance level is .05 .

Fig. 3. Binomial test: managerial level and servant leadership

The analysis above showed the $p$-value to be 0.890 , and being greater than the prescribed 0.05 , with regards to the perceptions of the respondents that showed enough statistical evidence at the $95 \%$ confidence level to conclude that there was no relationship found to exist between managerial level and knowledge of servant leadership.

\section{Relationship between demographic data and awareness of emotional intelligence}

The One-Way ANOVA analysis was computed to determine if there was association between demographic data from the 211 respondents and their awareness of the construct of emotional intelligence and the results, as shown in Table 4 below.

Table 4 ANOVA analysis - perceived awareness of emotional intelligence

\begin{tabular}{|c|c|c|c|c|c|c|}
\hline & & $\begin{array}{l}\text { Sum of } \\
\text { squares }\end{array}$ & $d f$ & Mean square & $\mathrm{F}$ & Sig. \\
\hline \multirow{3}{*}{ Gender } & Between groups & 1.704 & 4 & .426 & 2.062 & .087 \\
\hline & Within groups & 41.726 & 202 & .207 & & \\
\hline & Total & 43.430 & 206 & & & \\
\hline \multirow{3}{*}{ Age range } & Between groups & 1.237 & 4 & .309 & .529 & .715 \\
\hline & Within groups & 117.540 & 201 & .585 & & \\
\hline & Total & 118.777 & 205 & & & \\
\hline \multirow{3}{*}{ Highest educational qualification } & Between groups & 5.880 & 4 & 1.470 & 2.681 & .033 \\
\hline & Within groups & 110.222 & 201 & .548 & & \\
\hline & Total & 116.102 & 205 & & & \\
\hline \multirow{3}{*}{ Managerial level } & Between groups & 1.194 & 4 & .299 & .396 & .811 \\
\hline & Within groups & 150.786 & 200 & .754 & & \\
\hline & Total & 151.980 & 204 & & & \\
\hline \multirow{3}{*}{$\begin{array}{l}\text { Number of years of working in the } \\
\text { banking sector }\end{array}$} & Between groups & 5.684 & 4 & 1.421 & .741 & .565 \\
\hline & Within groups & 383.565 & 200 & 1.918 & & \\
\hline & Total & 389.249 & 204 & & & \\
\hline \multirow{3}{*}{$\begin{array}{l}\text { Years of experience in a managerial } \\
\text { position in the banking sector }\end{array}$} & Between groups & 3.038 & 4 & .759 & .512 & .727 \\
\hline & Within groups & 297.977 & 201 & 1.482 & & \\
\hline & Total & 301.015 & 205 & & & \\
\hline \multirow{2}{*}{$\begin{array}{l}\text { Attending leadership development } \\
\text { courses in the banking sector }\end{array}$} & Between groups & 1.733 & 4 & .433 & 3.990 & .004 \\
\hline & Within groups & 21.711 & 200 & .109 & & \\
\hline
\end{tabular}


Table 4 (cont.). ANOVA analysis - perceived awareness of emotional intelligence

\begin{tabular}{|c|c|c|c|c|c|c|}
\hline & & $\begin{array}{l}\text { Sum of } \\
\text { squares }\end{array}$ & $d f$ & Mean square & $\mathrm{F}$ & Sig. \\
\hline & Total & 23.444 & 204 & & & \\
\hline \multirow{3}{*}{ Number of leadership courses attended } & Between groups & 7.129 & 4 & 1.782 & 2.576 & .039 \\
\hline & Within groups & 121.065 & 175 & .692 & & \\
\hline & Total & 128.194 & 179 & & & \\
\hline \multirow{3}{*}{$\begin{array}{l}\text { Attended a course on servant leader- } \\
\text { ship }\end{array}$} & Between groups & 2.253 & 4 & .563 & 2.965 & .021 \\
\hline & Within groups & 37.991 & 200 & .190 & & \\
\hline & Total & 40.244 & 204 & & & \\
\hline \multirow{3}{*}{$\begin{array}{l}\text { Attended a course on emotional } \\
\text { intelligence }\end{array}$} & Between groups & 9.259 & 4 & 2.315 & 11.120 & .000 \\
\hline & Within groups & 41.427 & 199 & .208 & & \\
\hline & Total & 50.686 & 203 & & & \\
\hline
\end{tabular}

With regard to the magnitude of the $p$-values, the most significant determinant of the perceived awareness was whether one had attended a course on emotional intelligence, followed by whether one had attended leadership development courses in the banking sector. It was established that those who had attended a course on servant leadership were more likely to be knowledgeable of emotional intelligence. On the other hand, respondents with higher academic qualifications were more knowledgeable of the concept of emotional intelligence compared to those who had lower academic qualifications.

\section{Relationship between managerial level and emotional intelligence}

The Pearson Chi-square analysis was computed to determine if one's knowledge of the construct of emotional intelligence was dependent on the managerial level and the results are presented in Table 5 below

Hypothesis Test: $\quad$ Pearson Chi-Square Analysis

Significance Level: $\quad 95 \%(p=0.05) ; 3 d f$

Rejection Criteria: $\quad$ reject $H_{0}$ if $p \leq 0.05$; accept $H_{0}$ if $p>0.05$

The results from the analysis are presented in Table 5 below.

Table 5. Chi-square analysis - emotional intelligence and managerial level

\begin{tabular}{|l|c|c|c|}
\hline & Value & df & Asymp. Sig. (2-sided) \\
\hline Pearson Chi-square & $10.340^{\mathrm{a}}$ & 3 & .016 \\
\hline Likelihood Ratio & 10.141 & 3 & .017 \\
\hline Linear-by-Linear Association & 6.898 & 1 & .009 \\
\hline N of valid cases & 203 & & \\
\hline a. 1 cells (12.5\%) have expected count less than 5. The minimum expected count is 4.33. \\
\hline
\end{tabular}

From the analysis above, the computed Chi-square statistic was 10.340, along with a p-statistic of 0.016 . The latter being less than 0.05 , there was sufficient statistical evidence at the $95 \%$ confidence level to validate that knowledge of emotional intelligence is a dependent of the managerial level.

\section{Impact of servant leadership on bank performance factors}

A one-sample t-test analysis was undertaken to measure the impact of servant leadership on bank business performance factors. The test was calculated based on the following hypotheses:

Test: one-sample t-test

Significance: 2-tailed, 95\% confidence level, 205 degrees of freedom.

Hypothesis:

$H_{0}$ : Servant leadership does not have an impact on bank performance. $\mathrm{H}_{1}$ : Servant leadership has an impact on bank performance.

Rejection criteria: $\quad$ reject $H_{0}$ if $p<0.05$; accept $H_{0}$ if $p>0.05$.

Table 6. One sample t-test - servant leadership on bank performance factors

\begin{tabular}{|c|c|c|c|c|c|c|}
\hline \multirow{3}{*}{ Bank performance factors } & \multicolumn{6}{|c|}{ Test value $=2.5$} \\
\hline & \multirow{2}{*}{$t$} & \multirow{2}{*}{$d f$} & \multirow{2}{*}{$\begin{array}{c}\text { Sig. } \\
\text { (2-tailed) }\end{array}$} & \multirow{2}{*}{ Mean difference } & \multicolumn{2}{|c|}{$95 \%$ confidence interval of the difference } \\
\hline & & & & & Lower & Upper \\
\hline Increased customer retention & 20.150 & 203 & .000 & .838 & .76 & .92 \\
\hline Better corporate governance & 12.471 & 205 & .000 & .617 & .52 & .71 \\
\hline Increased revenue & 15.977 & 204 & .000 & 685 & .60 & .77 \\
\hline Increased profitability & 14.979 & 203 & .000 & .686 & .60 & .78 \\
\hline Improved overall bank performance & 20.339 & 204 & .000 & .846 & .76 & .93 \\
\hline
\end{tabular}


From the results, it can be seen that all the measures of business performance had corresponding $p$-values of 0.000 . The latter being less than 0.05 , it follows from the rejection criteria determined above that we rejected the null hypothesis for all the variables and accepted the alternative hypothesis that a significant relationship was found to exist between servant leadership and each of the business performance factors.

\section{Impact of emotional intelligence on bank performance factors}

A one-sample t-test analysis was undertaken to measure the impact of emotional intelligence on bank business performance factors. The test was calculated based on the following hypotheses:

Test: one-sample t-test

Significance: 2-tailed, 95\% confidence level, 205 degrees of freedom.

Hypothesis:

$H_{0}$ : Emotional intelligence does not have an impact on bank performance. $\mathrm{H}_{1}$ : Emotional intelligence has an impact on bank performance.

Rejection criteria: $\quad$ reject $H_{0}$ if $p<0.05$; accept $H_{0}$ if $p>0.05$

The results from the computation are presented in the Table 7 below.

Table 7. One sample t-test - emotional Intelligence on bank performance factors

\begin{tabular}{|c|c|c|c|c|c|c|}
\hline \multirow{3}{*}{ Bank performance factors } & \multicolumn{6}{|c|}{ Test value $=2.5$} \\
\hline & \multirow{2}{*}{$t$} & \multirow{2}{*}{$\mathrm{df}$} & \multirow{2}{*}{$\begin{array}{l}\text { Sig. } \\
\text { (2-tailed) }\end{array}$} & \multirow{2}{*}{ Mean difference } & \multicolumn{2}{|c|}{$\begin{array}{l}95 \% \text { confidence Interval of the } \\
\text { difference }\end{array}$} \\
\hline & & & & & Lower & Upper \\
\hline Increased customer retention & 16.762 & 207 & .000 & .678 & .60 & .76 \\
\hline Better corporate governance & 8.828 & 207 & .000 & .413 & .32 & .51 \\
\hline Increased revenue & 12.439 & 207 & .000 & .529 & .45 & .61 \\
\hline Increased profitability & 13.299 & 207 & .000 & .553 & .47 & .63 \\
\hline Improved overall bank performance & 17.042 & 209 & .000 & .667 & .59 & .74 \\
\hline
\end{tabular}

From the above table, all the measures of business performance had corresponding p-values of 0.000 . The latter being less than 0.05 , it follows from the rejection criteria stated above that we rejected the null hypothesis for all the variables and accepted the alternative hypothesis that there was a significant relationship between emotional intelligence and each of the business performance factors. 